\title{
Sustainable optimization of nitrogen uses in oat at sowing and top-dressing stages
}

\author{
Douglas C. Reginatto', José Antonio Gonzalez da Silva², Roberto Carbonera ${ }^{2}$, Cleusa Adriane Menegassi \\ Bianchi $^{2}$, Felipe Libardoni ${ }^{2}$, Adriana Roselia Kraisig ${ }^{1}$, Ivan Ricardo Carvalho ${ }^{2 *}$, Juliana Aozane da Rosa ${ }^{1}$, Cibele \\ Luisa Peter ${ }^{1}$, Natiane Carolina Ferrari Basso², Júlio Daronco Berlezi ${ }^{2}$ and Felipe Uhde Porazzi ${ }^{2}$
}

\author{
${ }^{1}$ Departament of Exact Science and Engineering, Regional Northwest University of Rio Grande do Sul, 3000 Comércio \\ Street, ljuí, RS, 98700-000, Brazil \\ ${ }^{2}$ Departament de Estudos Agrários, Regional Northwest University of Rio Grande do Sul, 3000 Comércio Street, ljuí, RS, \\ 98700-000, Brazil
}

*Corresponding author: carvalho.irc@gmail.com

\begin{abstract}
The most efficient nitrogen management by adjusting the nutrient dose at sowing and top-dressing with the supply period can increase the oat yield with greater sustainability. Considering the main cereal succession systems in Brazil and independent of the agricultural year condition, the objective of the study was to propose combination of nitrogen adjusted dose at sowing and at top-dressing with the most adequate moment of supply over the biomass and oat grain yield. The experiment was conducted in the years 2015,2016 and 2017, in Augusto Pestana, RS, Brazil. The experimental plot was a randomized block design with four replicates, in a $4 \times 4$ factorial model, and four nitrogen rates at sowing ( 0 - control sample, 10, 30 and $60 \mathrm{~kg} \mathrm{ha}^{-1}$ ), changing the top-dressing dose at total of 70 and $100 \mathrm{~kg} \mathrm{ha}^{-1}$ in soybean / oat succession system and maize / oats, respectively. Expecting $4000 \mathrm{~kg} \mathrm{ha}^{-1}$ of grain yield, with top-dressing supply in four periods $(0,10,30$ and 60 days after the emergency). The nitrogen management in oat, the combination of the adjusted dose at sowing and at top-dressing with the supply season shows the need to combine the technical recommendations of fertilization with the meteorological conditions of cropping. The absence of nitrogen at sowing and total dose applied at top-dressing, 30 to 35 days after emergence, increased the biomass and grains yield, regardless of condition of the agricultural year and succession system.
\end{abstract}

Keywords: Avena sativa; fertilization; yield; response surface; sustainability.

Abbreviations: Al_Aluminum; Al_intermediate condition; $\beta_{3} X_{j}^{2}$ e $\beta_{4} Y_{j}^{2}$ - bending effects; $\beta_{5} X_{j} Y_{j}$ effects of interactions; BP_Total biomass productivity; BY_biomass yield; $\beta_{n_{-}}$estimation of regression coefficients; $\beta_{1} X_{j}$ e $\beta_{2} Y_{j-}$ main effect of the interaction of treatment levels; Ca_calcium; $\mathrm{C} / \mathrm{N}_{-}$carbon nitrogen relation; $\varepsilon_{\mathrm{j}}$ Error_From the response surface model; FY_favorable year; $\mathrm{GY} \_$grain yield; $\mathrm{pH} \_$hydrogen potential; $\mathrm{K} \_$potassium; K2O_potassium fertilizer; Mg_magnesium; Max_Maximum temperature; MS_mean square; Min_Minimum temperature; NS_N-dose sowing; N-fertilizer_nitrogen fertilizer; N_nitrogen; NC_N period top-dressing; OM_organic matter; P_phosphor; P2O5_phosphor fertilizer; $\mathrm{R}^{2}$ _determination coefficient; UY_unfavorable year; V3_vegetative growth stage; V6_ vegetative growth stage; $X_{-}$coded values of treatment levels nitrogen rates at sowing; $Y_{-}$coded values of treatment levels supply period at top-dressing; $Z_{i_{-}}$dependent variable; $Z_{-}$independent variable.

\section{Introduction}

The oats productivity potential is related with the genetic features of the cultivars and their interaction with meteorological conditions and management technologies. Among the management technologies, the dose and period of $\mathrm{N}$-fertilizer supply are fundamental to increase productivity (Flores et al., 2012; Mantai et al., 2015). In the yield expectation, the total dose to apply depends on the soil organic matter, the succession system and the desired yield. It is highlighted that in cereals such as wheat and oats, the total dose to be supplied considers its use at sowing and at top- dressing in the productivity expectation (Arenhardt et al., 2015, Mantai et al., 2016).

In the nitrogen supply, the most expressive amount is directed to top-dressing, but at the apply moment are not always obtained the best conditions of soil moisture and air temperature, causing nutrient losses, bringing on economic and environmental serious damages (Arenhardt et al al., 2015, Marolli et al., 2017). In this way, the greater efficiency of the nitrogen use by the period of supply at top-dressing can be defined considering more favorable meteorological conditions. This justify the anticipation or delay in supply within the range 
of greater requirement of the nutrient by the plant, on the emergency until 60 days of development (Mantai et al., 2016; Marolli et al., 2017).

In the perspective of achiving greater efficiency with sustainability nitrogen use in oats, there is the possibility of maximizing the total dose to be applied due to sowing. In this line of thought, in wheat and beans, the viability and benefits of the $\mathrm{N}$-fertilizer dose were observed totally or in greater amount at the sowing period (Teixeira Filho et al., 2010, Moreira et al., 2013). The sowing fertilization protect nitrogen from the sunlight and high air temperature, it keeps the nutrient closer to the roots, which brings the hypothesis of allowing better use efficiency by oat.

Considering the main cereal succession systems in Brazil and independent of the agricultural year condition, the objective of the study was to propose, the combination of the nitrogen adjusted dose at sowing and at top-dressing with the most adequate moment of supply over the biomass and oat grain yield.

\section{Results and discussion}

\section{Meteorological elements and nitrogen fertilizer management}

In Table 2, in the year 2015 the rainfall was similar to the historical average of the last 25 years. Expressive values of precipitation were observed at the beginning of the growing cycle, especially in the conditions which top-dressing was performed 10 and 30 days after emergence. The $\mathrm{N}$ supply at 60 days after emergence was in the condition of low soil moisture (Figure 1). Although the $\mathrm{N}$ fertilizer applied at different period will expected $4000 \mathrm{~kg}$ ha $^{-1}$ yield, the average grain yield obtained this year $\left(\bar{x}=3283 \mathrm{~kg} \mathrm{ha}^{-1}\right)$ indicate an intermediate condition (Al) of oats crop (Figure1, Table 2).

In the year 2016, rainfall was lower than the historical average, but with adequate distribution over the cycle. The temperatures were milder and with some stability during the crop (Table 2). $\mathrm{N}$-fertilizer was applied at 10 and 30 days after emergence and had adequate conditions of soil moisture due to rainfall that occurred prior to fertilization (Figure 1). The adequate distribution of rainfall with mild temperatures during the cycle promoted a grain yield average similar to the expected of $4000 \mathrm{~kg} \mathrm{ha}^{-1}$, justifying a favorable year (FY) for oats crop (Figure 1, Table 2). In 2017, the rainfall volume was lower than the historical average (Table 2) with irregular distribution along the cycle (Figure 1). It was also observed higher and unstable temperatures in comparison to other years. The fertilization at 10 and 30 days after emergence was under low soil moisture conditions due to the long period without precipitation, except for fertilization at 60 days after emergence (Figure 1). The higher temperatures combined with low soil moisture at the fertilization moments promoted 1979 $\mathrm{kg} \mathrm{ha}^{-1}$ of grain yield, well below the expectation of $4000 \mathrm{~kg} \mathrm{ha}$ 1 , justifying an unfavorable year (UY) to the oat crop (Figure 1, Table 2).

The agriculture has a strong dependence on meteorological elements that can promote yield oscillations over the years (Santos et al., 2011; Caron et al., 2017). Rainfall precipitation stands out as one of the main responsible for these variations (Marolli et al., 2017). The previous knowledge of precipitation conditions may indicate ways of management that ensure the success of agricultural activity (Arf et al., 2012). In the winter cereals, rainfall without large volumes, however, that favors adequate soil moisture, and well distributed throughout the cycle, characterize a favorable environment to higher productivity expression (Castro et al., 2012; Souza et al., 2013). Besides precipitation, the air temperature also acts with strong action over the productivity expression. The temperature works as a catalyst for the biological processes, which is why plants require a minimum and maximum temperature for physiological activities homeostasis (Tonin et al., 2014; Marolli et al., 2017). In grains such as oat and wheat, the milder temperatures and radiation quality favors tillering and grain filling, effects related to productivity (Castro et al., 2012; Arenhardt et al., 2015). It is remarkable in the nitrogen management, the occurrence of high volume and / or intensity of rains shortly after fertilization, generate large nutrient losses due to leaching (Ercoli et al., 2013; Scremin et al., 2017). The same authors show that higher temperatures also cause considerable nutrient losses by volatilization, without mention, the plant lower transpiration rate or even the closure of the stomata. This affect nutrient absorption and reflect in the productivity.

\section{Grain yield as a function of nitrogen aplplication}

In the analysis variance summary (not shown), differences were observed between the 16 combinations of nitrogen rates at sowing / top-dressing with the supply seasons on the biomass and grain yield expression, regardless of the agricultural year conditionin and the systems succession. Therefore, the analysis proceeded in the average comparison to identify most promising combinations to increase productivity (Table 3 ).

In the Table 3, in the soybean / oat system, the intermediate crop year (2015) showed higher grain yield with 0,10 and 30 $\mathrm{kg} \mathrm{ha}^{-1}$ of $\mathrm{N}$-fertilizer doses at sowing and 70,60 and $40 \mathrm{~kg} \mathrm{ha}^{-1}$ at top-dressing, respectively, when supply 30 days after the emergence. These same combinations were also the most promising in increasing biomass productivity. In the favorable year (2016), the highest grain yield was obtained in the 0 and $10 \mathrm{~kg} \mathrm{ha}^{-1}$ of $\mathrm{N}$-fertilizer doses at sowing combined with 70 and $60 \mathrm{~kg} \mathrm{ha}^{-1}$ at top-dressing, respectively, were supplied at 10 and 30 days after the plants emergence. These conditions are also among the most effective in increased the biomass productivity expression. In the unfavorable year (2017), the highest grain yield was obtained at 10 and $30 \mathrm{~kg} \mathrm{ha}^{-1}$ of $\mathrm{N}$ fertilizer doses at sowing combined with $\mathrm{N}$-fertilizer doses 70 , 60 and $40 \mathrm{~kg} \mathrm{ha}^{-1}$ at top-dressing respectively, similar to the intermediate year. However, it indicated the need to anticipate supply to 10 days after the emergency. The biomass productivity expression was also among the most efficient in these combinations. By 2017, with the most restrictive conditions of the agricultural year, it may had promoted this supply anticipation as a response of the plant whom need greater stimulus to development in an unfavorable condition. In general, in the soybean / oat system (Table 3), independent of the agricultural year conditions, the most significant values of biomass and grain yield were in the 0 and $10 \mathrm{~kg} \mathrm{ha}^{-1}$ of $\mathrm{N}$ fertilizer at sowing with the total dose $\left(70 \mathrm{~kg} \mathrm{ha}^{-1}\right)$ and $60 \mathrm{~kg}$ 
ha $^{-1}$ at top-dressing, respectively, applied around 30 days after emergence.

In Table 3, in the maize / oat system, independent of the agricultural year condition, the most expressive values of grain yield were 0 and $10 \mathrm{~kg} \mathrm{ha}^{-1}$ of $\mathrm{N}$-fertilizer at sowing with 100 and $90 \mathrm{~kg} \mathrm{ha}^{-1}$ of $\mathrm{N}$-fertilizer at top-dressing respectively. In the total dose of $100 \mathrm{~kg} \mathrm{ha}^{-1}$ for the $4000 \mathrm{~kg} \mathrm{ha}^{-1}$ of grains expectation, when supplied at 10 and 30 days after emergence. Moreover, the highest biomass productivity was obtained with $\mathrm{N}$-fertilizer supply at sowing with 0,10 and $30 \mathrm{~kg}$ $\mathrm{ha}^{-1}$, combined with 100,90 and $70 \mathrm{~kg} \mathrm{ha}^{-1}$ respectively, supplied at 10 o 30 days after emergence, regardless of the agricultural year condition. In this system, it was observed a greater amplitude in the moment of the fertilization at topdressing, mainly due to the need of anticipated $\mathrm{N}$-fertilizer use. This result may have been necessary due to the higher Carbon / Nitrogen ratio of the maize / oats system, becaming difficult to release $\mathrm{N}$-residual at the beginning of plant development. It required anticipation of $\mathrm{N}$-fertilizer supply to meet oat needs. In general, conditions with 0 and $10 \mathrm{~kg} \mathrm{ha}^{-1}$ of nitrogen at sowing combined with the remainder at top-dressing promote greater efficiency of nitrogen utilization in the biomass and grains for the desired expectation provided at 10 and 30 days after emergence, regardless of succession system and the agricultural year condition.

\section{Nutrient optimization in the maximum expression of biomass and grain yield}

In the perspective to adjust the ideal combination of the nitrogen dose at sowing / top-dressing with the supply period to have more sustainable optimization of nutrient use, Table 4 shows the mean square (MS) significance and the determination coefficient $\left(R^{2}\right)$ for validation of a response surface structure to nutrient optimization at the maximum expression of biomass and grain yield. In this perspective, it was verified that the independent variable of biomass and grain (Z) productivity shown significance of mean square with high determination coefficient in the complete structural model in the succession systems, it allowed to generate a mathematical structure of three-dimensional configuration that turned on possible to identify points combined optimization. Thus, in Table 5, it were presented the coefficients of the response surface equations considering the complete model. These equations were developed per agricultural year condition and succession system (soybean / oats and maize / oats).

The equations allowed estimating the maximum biomass and grains yield as a function of the ideal combination adjustment of the nitrogen dose per partial derivative at sowing / topdress with the time of supply after the emergence. From the established equations (Table 5), were shown in Figures 2 and 3 the graphical structure of three-dimensional surface of the nitrogen conditions use on the biomass and grain yield expression, respectively. The optimization results confirm that the ideal conditions of nitrogen management on the expression of biomass and grains productivity provided from 30 to 35 days after emergence were in absence of nitrogen at sowing with the total coverage dose for the $4000 \mathrm{~kg} \mathrm{ha}^{-1}$ of grain yield expectation, regardless of the agricultural year condition and the succession system.

\section{Definition of nitrogen fertilizer application in oats}

Altogether, the total fertilizer dose in oat is defined according to the soil organic matter content, the previous crop and the expected productivity (Mantai et al., 2016). Otherwise, the most favorable time for cover fertilization depends only on plant phenology linked to the period of greatest nutrient deficiency in the production components formation (Bredemeier et al., 2013). From the emergence to the emission of the sixth leaf is the period when the oat plants demand more nitrogen (Mantai et al., 2015). If it were applied in the initial stages, it favors the maximum number of spikelets and grains in the inflorescence. When it were applied in the final stages, can potentialize the number of stems per area (Teixeira Filho et al., 2010). Herewith, the Brazilian technical indications recommend as top-dressing period between the beginning of the tillering (stage V3) and beginning of the elongation (stage V6), interval around 30 to 60 days after the emergence for wheat and oats (Brezolin et al., 2017). According to Arenhardt et al. (2015), the period between the beginning of the tillering and the elongation shows a large interval in the decision of the appropriate application moment, requiring the most favorable conditions of soil moisture, and other elements to dimension the dose and the most adjusted moment to nutrient supply. In irrigated wheat, Teixeira Filho et al. (2010) verified the viability of total nitrogen supply at sowing, however, not differing from the traditional application who matches sowing and topdressing supply over productivity. In dry wheat, Ercoli et al. (2013) had observed greater nitrogen efficiency to grain yield with $30 \mathrm{~kg}$ ha- 1 of the nutrient application at the time of sowing and the total dose remainder at top-dressing. In canola, Kaefer et al. (2015) had observed an increase in the efficiency of nitrogen utilization to grains elaboration through dividing one third at sowing and two thirds at top-dressing (40 and 80 $\mathrm{kg} \mathrm{ha-1)}$ applied at the fourth true leaf stage. Studies indicate that the supply of fractionated nitrogen can reduce its losses by using partial doses at suitable period for fertilization, especially when the environmental conditions are not favorable for a single dose fertilization at top-dressing (Brezolin et al, 2016). In this context, the complex relationships between plant, climate and management should be considered in the definition of efficient and more sustainable management for the nitrogen supply in the productivity expression (Costa et al., 2018). Therefore, nitrogen management deserves attention, not only because of the high cost it represents, but also because of the conscious use, ensuring productivity with greater sustainability. Thus, the nitrogen dose at sowing and top-dressing with the appropriate moment of supply is important strategies to the nutrient optimization and utilization, especially when there is great variability of the cropping conditions that limit the efficiency, reduce the production and can generate environmental impacts. Moreover, the results presented on our study show an innovative proposal of nitrogen management in the oat crop, it seek to aggregate the standard criteria of fertilization recommendation with the meteorological conditions of 
Table 1. Nitrogen doses in oat sowing/top-dressing with the period of top-dressing supply in succession systems.

\begin{tabular}{|c|c|c|c|c|}
\hline $\begin{array}{l}\text { Sowing } \mathrm{N} \text { dose } \\
\left(\mathrm{Kg} \mathrm{ha}^{-1}\right)\end{array}$ & $\begin{array}{l}\text { Top-dressing } \mathrm{N} \text { dose } \\
\left(\mathrm{Kg} \mathrm{ha}^{-1}\right)\end{array}$ & $\begin{array}{l}\text { Total N dose } \\
\left(\mathrm{Kg} \mathrm{ha}^{-1}\right)\end{array}$ & $\begin{array}{l}\text { Grain Productivity Expectation } \\
\left(\mathrm{Kg} \mathrm{ha}^{-1}\right)\end{array}$ & $\begin{array}{l}\mathrm{N} \text { top-dressing period } \\
\text { (Days After Emergency) }\end{array}$ \\
\hline \multicolumn{5}{|c|}{ Soybean/oat System } \\
\hline 0 & 70 & \multirow{4}{*}{70} & \multirow{4}{*}{4000} & \multirow{4}{*}{$0 ; 10 ; 30 ; 60$} \\
\hline 10 & 60 & & & \\
\hline 30 & 40 & & & \\
\hline 60 & 10 & & & \\
\hline \multicolumn{5}{|c|}{ Maize/oat System } \\
\hline 0 & 100 & \multirow{4}{*}{100} & \multirow{4}{*}{4000} & \multirow{4}{*}{$0 ; 10 ; 30 ; 60$} \\
\hline 10 & 90 & & & \\
\hline 30 & 70 & & & \\
\hline 60 & 40 & & & \\
\hline
\end{tabular}
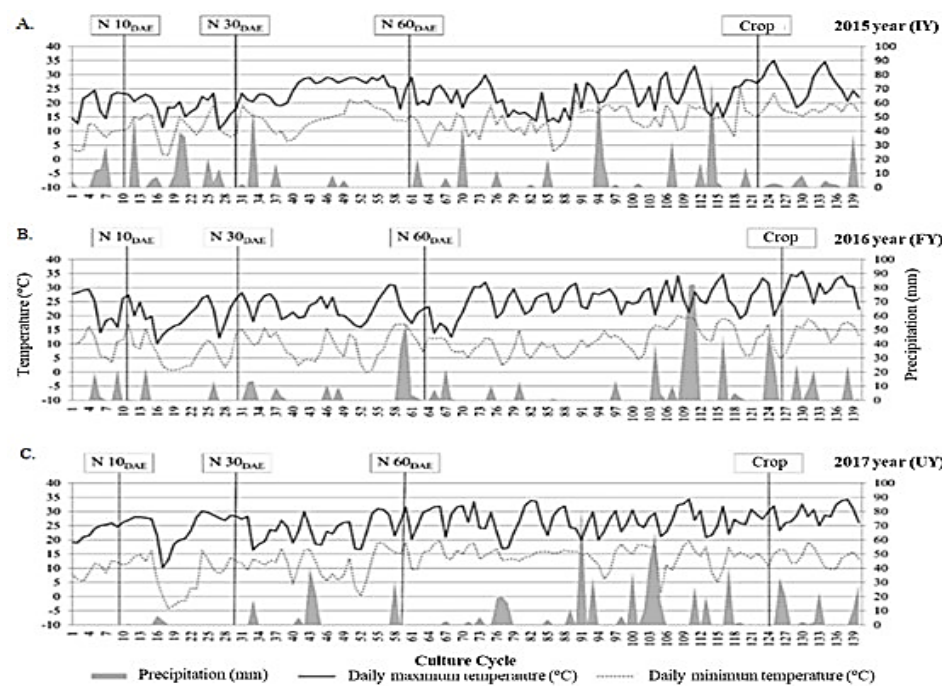

Figure 1. Rainfall data and minimum and maximum daily temperature in the oat crop cycle and the fertilization period, in the years 2015,2016 and 2017. Data obtained from the meteorological station located at the Regional Institute of Rural Development/IRDeR /UNIJUÍ. Sowing (2015): 09/06; Sowing (2016): 21/06; Sowing (2017): 22/06.

Table 2. Temperatures and rainfall in the oat crop cycle and grain yield in 2015, 2016 and 2017.

\begin{tabular}{|c|c|c|c|c|c|c|c|}
\hline \multirow{2}{*}{ Month } & \multicolumn{3}{|c|}{ Temperature $\left({ }^{\circ} \mathrm{C}\right)$} & \multicolumn{2}{|c|}{ Precipitation (mm) } & \multirow{2}{*}{ GY (Kg ha-1) } & \multirow{2}{*}{ Class } \\
\hline & Min & Max & Mean & 25 years* & Occurred & & \\
\hline \multicolumn{8}{|c|}{2015} \\
\hline June & 9.56 & 21.47 & 15.52 & 162.5 & 228.3 & \multirow{6}{*}{3283} & \multirow{6}{*}{ IY } \\
\hline July & 10.5 & 20.59 & 15.55 & 135.1 & 211.5 & & \\
\hline August & 13.3 & 24.8 & 19.05 & 138.2 & 86.8 & & \\
\hline September & 12.73 & 19.93 & 16.33 & 167.4 & 127.3 & & \\
\hline October & 16.7 & 25.2 & 20.95 & 156.5 & 161.8 & & \\
\hline Total & - & - & - & 909.4 & 815.7 & & \\
\hline \multicolumn{8}{|c|}{2016} \\
\hline June & 4.7 & 19.3 & 12.00 & 162.5 & 65.6 & \multirow{6}{*}{3925} & \multirow{6}{*}{$\mathrm{FY}$} \\
\hline July & 8.5 & 21.55 & 15.03 & 135.1 & 80.5 & & \\
\hline August & 9.4 & 22.5 & 15.95 & 138.2 & 160.0 & & \\
\hline September & 8.44 & 23.82 & 16.13 & 167.4 & 56.3 & & \\
\hline October & 13.3 & 25.8 & 19.55 & 156.5 & 325.8 & & \\
\hline Total & - & - & - & 909.4 & 688.2 & & \\
\hline \multicolumn{8}{|c|}{2017} \\
\hline June & 10.7 & 21.8 & 16.25 & 162.5 & 146.3 & \multirow{6}{*}{1979} & \multirow{6}{*}{ UY } \\
\hline July & 8.3 & 24.42 & 16.36 & 135.1 & 10.7 & & \\
\hline August & 11.4 & 23.7 & 17.55 & 138.2 & 117.8 & & \\
\hline September & 15.36 & 27.07 & 21.22 & 167.4 & 161.5 & & \\
\hline October & 14.7 & 27.8 & 21.25 & 156.5 & 304.0 & & \\
\hline Total & - & - & - & 909.4 & 740.3 & & \\
\hline
\end{tabular}


Table 3. Average yield of biomass and oat grain by the combination of $\mathrm{N}$-doses at sowing/top-dressing with top-dressing supply period in succession systems.

\begin{tabular}{|c|c|c|c|c|c|c|c|}
\hline \multirow{2}{*}{$\begin{array}{l}\mathrm{N} \text { dose } \\
\text { Sowing - Top-dressing } \\
\left(\mathrm{kg} \mathrm{ha}^{-1}\right)\end{array}$} & \multirow{2}{*}{$\begin{array}{l}\text { N period } \\
\text { Top-dressing } \\
\text { (days) }\end{array}$} & \multicolumn{3}{|c|}{ GY $\left(\mathrm{kg} \mathrm{ha}^{-1}\right)$} & \multicolumn{3}{|c|}{ BY $\left(\mathrm{kg} \mathrm{ha}^{-1}\right)$} \\
\hline & & $\begin{array}{l}2015 \\
\text { (IY) }\end{array}$ & $\begin{array}{l}2016 \\
\text { (FY) }\end{array}$ & $\begin{array}{l}2017 \\
\text { (UY) }\end{array}$ & $\begin{array}{l}2015 \\
\text { (IY) }\end{array}$ & $\begin{array}{l}2016 \\
\text { (FY) }\end{array}$ & $\begin{array}{l}2017 \\
\text { (UY) }\end{array}$ \\
\hline \multicolumn{8}{|c|}{ Soybean/oat system } \\
\hline $0-70$ & 0 & $2016 \mathrm{e}$ & $2649 \mathrm{~d}$ & $1421 \mathrm{c}$ & $5771 \mathrm{e}$ & $8051 d$ & $4624 \mathrm{c}$ \\
\hline $0-70$ & 10 & $3224 \mathrm{~b}$ & 3730 a & $2496 a$ & $8530 \mathrm{c}$ & 10970 a & $6870 a$ \\
\hline $0-70$ & 30 & 3525 a & $4056 \mathrm{a}$ & $2006 \mathrm{~b}$ & $11228 \mathrm{a}$ & 11192 a & $6422 a$ \\
\hline $0-70$ & 60 & $2330 d$ & $2873 d$ & $1862 \mathrm{~b}$ & $7682 c$ & $9073 \mathrm{c}$ & $5335 \mathrm{c}$ \\
\hline $10-60$ & 0 & 2059 e & $2846 \mathrm{~d}$ & $1505 c$ & $6717 d$ & $8586 \mathrm{~d}$ & 5072 c \\
\hline $10-60$ & 10 & $3094 \mathrm{~b}$ & $3495 \mathrm{~b}$ & $2274 a$ & $8670 \mathrm{c}$ & $10350 \mathrm{~b}$ & $6537 a$ \\
\hline $10-60$ & 30 & 3440 a & 3795 a & $1951 \mathrm{~b}$ & $10562 \mathrm{a}$ & $11446 a$ & $6325 a$ \\
\hline $10-60$ & 60 & $2314 d$ & $3073 \mathrm{c}$ & $1887 \mathrm{~b}$ & $7888 \mathrm{c}$ & 9416 c & $5889 \mathrm{~b}$ \\
\hline $30-40$ & 0 & $2104 \mathrm{e}$ & $3036 c$ & $1722 \mathrm{~b}$ & $8612 c$ & $10004 \mathrm{~b}$ & $5119 \mathrm{c}$ \\
\hline $30-40$ & 10 & $2825 c$ & $3375 \mathrm{~b}$ & $2201 \mathrm{a}$ & $9291 \mathrm{~b}$ & $10667 \mathrm{~b}$ & $5929 \mathrm{~b}$ \\
\hline $30-40$ & 30 & $3393 \mathrm{a}$ & $3611 \mathrm{~b}$ & $1942 \mathrm{~b}$ & $10602 \mathrm{a}$ & 11118 a & $5887 \mathrm{~b}$ \\
\hline $30-40$ & 60 & $2355 d$ & $3339 \mathrm{~b}$ & $1901 \mathrm{~b}$ & 8194 c & 10586 b & $5875 \mathrm{~b}$ \\
\hline $60-10$ & 0 & $2369 d$ & $2840 d$ & $1778 \mathrm{~b}$ & $8269 \mathrm{c}$ & 9817 b & 5492 c \\
\hline $60-10$ & 10 & $2690 \mathrm{~d}$ & 3207 c & 1912 b & $9344 \mathrm{~b}$ & $9899 \mathrm{~b}$ & $5722 b$ \\
\hline $60-10$ & 30 & $3138 \mathrm{~b}$ & 3375 b & $1882 \mathrm{~b}$ & 9244 b & 10362 b & $5829 \mathrm{~b}$ \\
\hline $60-10$ & 60 & $2410 d$ & $3236 c$ & $1831 \mathrm{~b}$ & $9335 \mathrm{~b}$ & $10276 b$ & $5880 \mathrm{~b}$ \\
\hline \multicolumn{8}{|l|}{ Maize/oat system } \\
\hline $0-100$ & 0 & $1794 \mathrm{~d}$ & $2275 d$ & $1063 d$ & $5894 \mathrm{~d}$ & 7916 c & 3585 c \\
\hline $0-100$ & 10 & 3592 a & $4220 \mathrm{a}$ & $2305 a$ & $8649 a$ & $10293 \mathrm{a}$ & $5888 \mathrm{a}$ \\
\hline $0-100$ & 30 & 3364 a & $4073 a$ & $2113 a$ & $8653 \mathrm{a}$ & $10481 \mathrm{a}$ & $5930 \mathrm{a}$ \\
\hline $0-100$ & 60 & $2394 \mathrm{c}$ & 2687 c & $1358 \mathrm{c}$ & $6271 \mathrm{~d}$ & 8846 b & $4740 \mathrm{~b}$ \\
\hline $10-90$ & 0 & $1984 \mathrm{~d}$ & $2501 d$ & $1078 \mathrm{~d}$ & $6460 d$ & $7654 \mathrm{c}$ & 3797 c \\
\hline $10-90$ & 10 & 3279 a & 3879 a & $2129 a$ & 8621 a & $10551 \mathrm{a}$ & 5997 a \\
\hline $10-90$ & 30 & 3409 a & 3780 a & 2002 a & 9350 a & $10829 a$ & $5640 a$ \\
\hline $10-90$ & 60 & $2388 \mathrm{c}$ & $2783 c$ & $1351 \mathrm{c}$ & $7281 \mathrm{c}$ & $9194 \mathrm{~b}$ & $4437 \mathrm{~b}$ \\
\hline $30-70$ & 0 & $2288 \mathrm{c}$ & $3077 \mathrm{~b}$ & $1130 \mathrm{~d}$ & $7595 \mathrm{c}$ & 8587 b & $4782 \mathrm{~b}$ \\
\hline $30-70$ & 10 & $3038 \mathrm{~b}$ & $3235 \mathrm{~b}$ & $1973 \mathrm{a}$ & $8742 \mathrm{a}$ & 9945 a & $5505 a$ \\
\hline $30-70$ & 30 & 3415 a & $3366 \mathrm{~b}$ & $1665 \mathrm{~b}$ & 8961 a & $10406 \mathrm{a}$ & $5540 \mathrm{a}$ \\
\hline $30-70$ & 60 & 2442 c & $3009 \mathrm{~b}$ & $1384 \mathrm{c}$ & $7635 c$ & 9082 b & $4851 \mathrm{~b}$ \\
\hline $60-40$ & 0 & $2331 \mathrm{c}$ & 2780 c & $1048 d$ & $7385 \mathrm{c}$ & $9366 \mathrm{~b}$ & $4723 \mathrm{~b}$ \\
\hline $60-40$ & 10 & $2669 \mathrm{c}$ & $3122 b$ & $1647 \mathrm{~b}$ & $8393 \mathrm{~b}$ & $9363 \mathrm{~b}$ & $4857 \mathrm{~b}$ \\
\hline $60-40$ & 30 & $3022 b$ & 2967 b & 1592 b & 8709 a & $9596 \mathrm{~b}$ & $4431 b$ \\
\hline $60-40$ & 60 & $2331 \mathrm{c}$ & $2854 \mathrm{c}$ & $1226 \mathrm{~d}$ & $8618 \mathrm{a}$ & $9122 \mathrm{~b}$ & $4176 \mathrm{c}$ \\
\hline
\end{tabular}

N - Nitrogen; GY - Grain yield; BY - Total biomass yield; IY - intermediate year; FY - Favorable year; UY - unfavorable year; Means followed by the same letters constitute a statistically homogeneous group by the Skott \& Knott test with a $5 \%$ error probability.

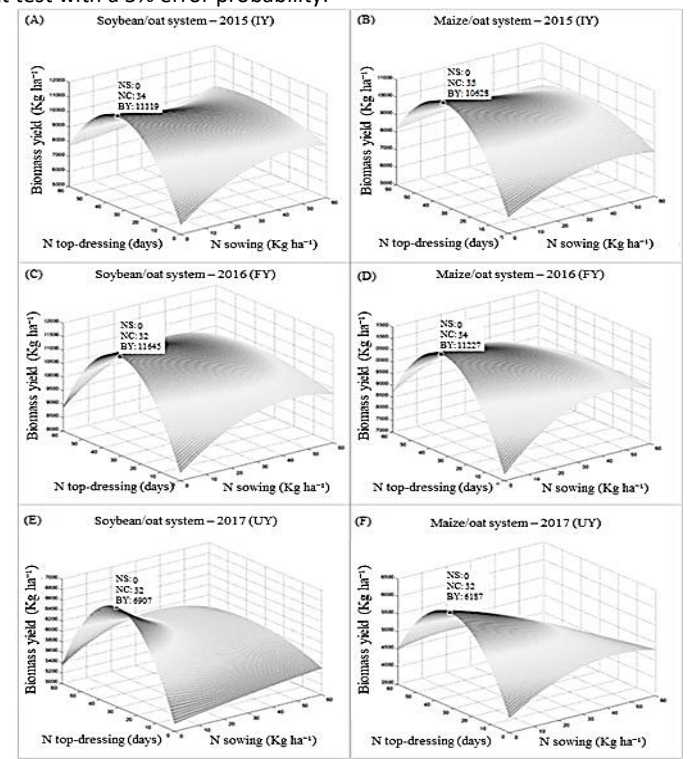

Figure 2. Optimization of the $\mathrm{N}$-doses at sowing/top-dressing with the top-dressing supply period to the biomass productivity in the conditions of agricultural year and succession system. NS - N-dose sowing $\left(\mathrm{kg} \mathrm{ha}^{-1}\right)$; NC - N period top-dressing (days after emergence); BY - Biomass yield (kg ha-1). 
Table 4. Response surface equation with model coefficients for $\mathrm{N}$-dose at sowing/top-dressing $(\mathrm{X})$ with top-dressing supply period ( $\mathrm{Y}$ ) in succession systems.

\begin{tabular}{|c|c|}
\hline \multirow{2}{*}{ Ano } & Response Surface Equation \\
\hline & $P G=a+b X+c X^{2}+d Y+e Y^{2}+f X Y+g X^{2} Y+h X Y^{2}+I X^{2} Y^{2}$ \\
\hline & Soybean/oat System \\
\hline 2015 (Al) & $2169-5.24 X+0.13 X^{2}+96.55 Y-1.57 Y^{2}-0.30 X Y-0.0078 X^{2} Y+0.0069 X Y^{2}+0.00009 X^{2} Y^{2}$ \\
\hline 2016 (AF) & $2817+13.38 X-0.20 X^{2}+85.99 Y-1.42 Y^{2}-2.63 X Y+0.028 X^{2} Y+0.047 X Y^{2}-0.00051 X^{2} Y^{2}$ \\
\hline \multirow[t]{2}{*}{2017 (AD) } & $1668+8.13 X-0.09 X^{2}+36.93 Y-0.57 Y^{2}-1.02 X Y+0.0086 X^{2} Y+0.016 X Y^{2}-0.00014 X^{2} Y^{2}$ \\
\hline & Maize/oat system \\
\hline 2015 (Al) & $2113+10.16 X-0.11 X^{2}+101.39 Y-1.63 Y^{2}-0.93 X Y+0.00012 X^{2} Y+0.02 X Y^{2}-0.00001 X^{2} Y^{2}$ \\
\hline $2016(\mathrm{AF})$ & $2578+25.81 X-0.35 X^{2}+122.79 Y-2.04 Y^{2}-4.78 X Y+0.049 X^{2} Y+0.079 X Y^{2}-0.00081 X^{2} Y^{2}$ \\
\hline 2017 (AD) & $1278+3.79 X-0.096 X^{2}+72.00 Y-1.19 Y^{2}-1.68 X Y+0.018 X^{2} Y+0.028 X Y^{2}-0.0003 X^{2} Y^{2}$ \\
\hline \multirow{3}{*}{ Ano } & Response Surface Equation \\
\hline & $P B=a+b X+c X^{2}+d Y+e Y^{2}+f X Y+g X^{2} Y+h X Y^{2}+i X^{2} Y^{2}$ \\
\hline & Soybean/oat system \\
\hline 2015 (Al) & $5666+132.64 X-1.42 X^{2}+325.46 Y-4.85 Y^{2}-8.46 X Y+0.065 X^{2} Y+0.11 X Y^{2}-0.00062 X^{2} Y^{2}$ \\
\hline $2016(\mathrm{AF})$ & $8307+78.63 X-0.89 X^{2}+212.63 Y-3.38 Y^{2}-5.93 X Y+0.05 X^{2} Y+0.10 X Y^{2}-0.00081 X^{2} Y^{2}$ \\
\hline \multirow[t]{2}{*}{2017 (AD) } & $5153+7.57 X-0.028 X^{2}+113.43 Y-1.83 Y^{2}-3.41 X Y+0.03 X^{2} Y+0.06 X Y^{2}-0.00061 X^{2} Y^{2}$ \\
\hline & Maize/oat system \\
\hline 2015 (Al) & $5956+77.37 X-0.85 X^{2}+281.87 Y-4.07 Y^{2}-5.82 X Y+0.038 X^{2} Y+0.08 X Y^{2}-0.00046 X^{2} Y^{2}$ \\
\hline 2016 (AF) & $7308+110.11 X-1.27 X^{2}+235.73 Y-3.54 Y^{2}-7.75 X Y+0.067 X^{2} Y+0.12 X Y^{2}-0.0011 X^{2} Y^{2}$ \\
\hline $2017(A D)$ & $3939+46.68 X-0.54 X^{2}+139.82 Y-2.17 Y^{2}-3.75 X Y+0.02 X^{2} Y+0.057 X Y^{2}-0.00032 X^{2} Y^{2}$ \\
\hline
\end{tabular}




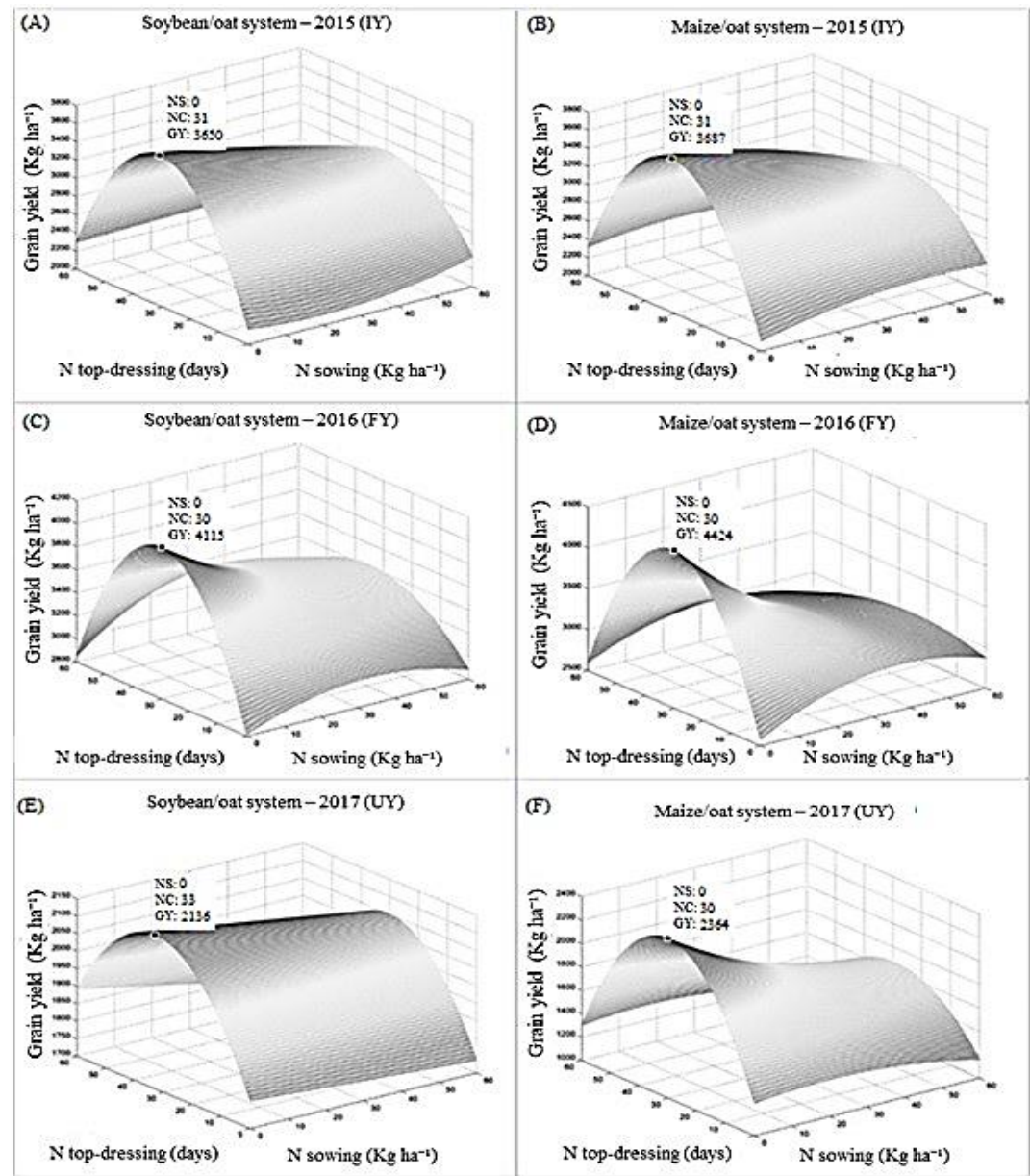

Figure 3. Optimization of the nitrogen dose at sowing/top-dressing with period top-dressing supply to grain yield under the conditions of the agricultural year and succession system. NS - N-dose sowing $\left(\mathrm{kg} \mathrm{ha}^{-1}\right)$; NC - N period top-dressing (days after emergence); GY - Grain yield (kg ha-1).

cultivation, with the perspective to have more sustainable management of the nutrient.

\section{Material and Methods}

\section{Plant materials}

The experiment was developed on field in the agricultural years of 2015, 2016 and 2017 in Augusto Pestana, RS, Brazil (28 - 26 ' $30^{\prime} \mathrm{S}$; $54^{\circ} 00^{\prime} 58$ " W). The growing soil of the experimental area is classify as typic dystroferric Red Latosol and the climate of the region, according to Köppen's classification, matches to CFA, with the occurrence of hot summers, no occurrence of prolonged droughts, and cold wet winters. The soil analysis was realized twenty days before sowing and had the following features chemistry: i) soybean/oat system $\left(\mathrm{pH}=6.2 ; \mathrm{P}=33.9 \mathrm{mg} \mathrm{dm}^{-3} ; \mathrm{K}=200 \mathrm{mg} \mathrm{dm}^{-}\right.$ 3; $\mathrm{OM}=3.0 \% ; \mathrm{Al}=0 \mathrm{cmol}_{\mathrm{c}} \mathrm{dm}^{-3} ; \mathrm{Ca}=6.5 \mathrm{cmol}_{\mathrm{c}} \mathrm{dm}^{-3}$ and $\mathrm{Mg}=$ $\left.2.5 \mathrm{cmol}_{c} \mathrm{dm}^{-3}\right)$ and maize/oat system $(\mathrm{pH}=6.5 ; \mathrm{P}=34.4 \mathrm{mg} \mathrm{dm}-$ 3; $\mathrm{K}=262 \mathrm{mg} \mathrm{dm}{ }^{-3} ; \mathrm{OM}=2.9 \% ; \mathrm{Al}=0 \mathrm{cmol}_{\mathrm{c}} \mathrm{dm}^{-3} ; \mathrm{Ca}=6.6 \mathrm{cmol}_{\mathrm{c}}$ $\mathrm{dm}^{-3}$ and $\left.\mathrm{Mg}=3.4 \mathrm{cmol}_{\mathrm{c}} \mathrm{dm}^{-3}\right)$. The sowing was performed in the third week on June using a seeder-fertilizer machine, composing plots with five 5 -m-length lines spaced by $0.20 \mathrm{~m}$, with an experimental unit of $5 \mathrm{~m}^{2}$. The population density was $400 \mathrm{~m}^{-2}$ viable seeds. During the study tebuconazole fungicide was applied at the dosage of $0.75 \mathrm{~L} \mathrm{ha}^{-1}$. The weeds were controlled by metsulfuron-methyl herbicide at dose of $4 \mathrm{~g} \mathrm{ha}^{-1}$. At the sowing were applied, 45 and $30 \mathrm{~kg} \mathrm{ha}^{-1}$ of P2O5 and $\mathrm{K} 2 \mathrm{O}$, respectively, based on the soil $\mathrm{P}$ and $\mathrm{K}$ contents, for 4000 $\mathrm{kg} \mathrm{ha}^{-1}$ grain yield expected.

\section{Experimental design and experimental procedure}

In each cropping system (soybean/oat and maize/oat), two experiments were conducted, one to quantify the total biomass yield and the other to estimate grain yield (GY, kg ha$\left.{ }^{1}\right)$ of the white oat cultivar Brisasul. Therefore, in the four experiments, the plot design was in a randomized block design with four replicates in a $4 \times 4$ factorial scheme, for four nitrogen rates at sowing $\left(0,10,30\right.$ and $\left.60 \mathrm{~kg} \mathrm{ha}^{-1}\right)$. The topdressing dose was change by the total provided 70 and $100 \mathrm{~kg}$ $\mathrm{ha}^{-1}$ in soybean/oat and maize/oat systems, respectively, for $4000 \mathrm{~kg} \mathrm{ha}^{-1}$ grain yield expected. The top-dressing supply in the four periods of application was $(0,10,30$ and 60 days after emergence), with 128 experimental units per succession system. The nitrogen rates at sowing and top-dressing were shown according to Table 1. 


\section{Traits measured}

The grain yield value was obtained by cutting the three central lines of each plot at harvest maturity, grain moisture close to $22 \%$. The plots were threshed with stationary threshing machine, the grain moisture corrected to $13 \%$ at the laboratory and weighed to grain yield (GY, $\mathrm{kg} \mathrm{ha}^{-1}$ ) estimative. The plant material was harvested close to the soil by collecting a linear meter in the three central lines of each plot at the physiological maturity to quantify biomass yield, around 120 days after emergence. The plant material were dried in a forced-air oven at temperature of 65 ㅇ $\mathrm{C}$ until stabilized weight to estimate biomass yield (BY, $\mathrm{kg} \mathrm{ha}^{-1}$ ). For the analysis of the agricultural years, the meteorological data of air temperature and rainfall were obtained through Total Automatic Station installed 500 meters from the experiment.

\section{Statistical analysis}

By following the assumptions of homogeneity and normality via Bartlet tests, the variance analysis was performed to detect the main interaction effects. Scott and Knott model was used to averages comparison for biomass and grain yield with the nitrogen doses at sowing/top-dressing with the supply seasons carried out, which created sixteen levels of treatments combination. In the adjustment of the ideal combination of $\mathrm{N}$ dose at sowing / top-dressing and supply period at topdressing. It was create a response surface regression analysis $\left(Z_{i}=\beta_{0}+\beta_{1} X_{j}+\beta_{2} Y_{j}+\beta_{3} X_{j}^{2}+\beta_{4} Y_{j}^{2}+\cdots+\beta_{n} X_{j} Y+\varepsilon_{j}\right)$ being, $Z_{i}=$ dependent variable (grain and biological yield); $\beta_{\mathrm{n}}=$ estimation of regression coefficients; $\mathrm{X} \mathrm{eY}=$ coded values of treatment levels [nitrogen rates at sowing $(0,10,30$, $\left.60 \mathrm{~kg} \mathrm{ha}^{-1}\right)$ and supply period in top-dressing $(0,10,30,60$ days after emergence)]; $\beta_{1} X_{j}$ e $\beta_{2} Y_{j}=$ main effect of the interaction of treatment levels; $\beta_{3} \mathrm{X}_{\mathrm{j}}^{2}$ e $\beta_{4} \mathrm{Y}_{\mathrm{j}}^{2}=$ bending effects; $\beta_{5} X_{j} Y_{j}=$ effects of interactions; $\varepsilon_{j}=$ Error. From the response surface model, it was estimated by partial derivatives $\left(X_{\text {ideal }}=\frac{\partial G Y}{\partial X}\right.$ e $\left.Y_{\text {ideal }}=\frac{\partial G Y}{\partial Y}\right)$ the ideal combination of the nitrogen dose at sowing and supply period at topdressing in the cropping systems. It was used Genes computational program for those determinations and MATLAB ${ }^{\circledR}$ software was used to develop the graphic designs of surface response optimization.

\section{Conclusions}

In the nitrogen management in oats, the combination of the adjusted dose at sowing and at top-dressing with the supply season, shows the need to combine the technical recommendations of fertilization with the meteorological conditions of croping. The absence of nitrogen at sowing and applied of the total coverage dose provided 30 to 35 days after emergence, increased the biomass and grains yield, regardless the agricultural year condition and the succession system.

\section{Acknowledgements}

To CNPq, CAPES, FAPERGS and UNIJUÍ, for the contribution of the resources destined to the development of this study and for the scholarships of Scientific and Technological Initiation,
Technical Support, Post-graduation and Productivity in Research.

\section{References}

Arenhardt EG, Silva JAG, Gewehr E, Oliveira AC, Binelo MO, Valdiero AC, Gzergorczick ME, Lima ARC (2015) The nitrogen supply in wheat cultivation dependent on weather conditions and succession system in southern Brazil. Afri J Agric Res. 10:4322-4330.

Arf O, Nascimento V, Rodrigues RAF, Alvarez RCF, Gitti DC, Sá ME (2012) Uso de etil-trinexapac em cultivares de arroz de terras altas. Pesq Agrop Trop. 42:150- 158.

Bredemeier C, Variani C, Almeida D, Rosa AT (2013) Estimativa do potencial produtivo em trigo utilizando sensor óptico ativo para adubação nitrogenada em taxa variável. Ciê Rur. 43:1147-1154.

Brezolin AP, Silva JAG, Roos-Frantz FC, Binelo MO, Valdiero AC, Zimmer CM, Mantai RD, Marolli A, Scremin OB, Mazurkievicz G (2016) The efficiency of wheat yields by nitrogen dose and fractionation. Afri J Agric Res.11:3440-3449.

Brezolin AP, Silva JAG, Roos-Frantz FC, Binelo MO, Kruger CAMB, Arenhardt EG, Marolli A, Mantai RD, Scremin OB, Dornelles EF (2017) Wheat yield obtained from nitrogen dose and fractionation. Acad J. 12:566-576.

Caron BO, Oliveira DM, Elli EF, Eloy E, Schwerz F, Souza VQ (2017) Elementos meteorológicos sobre características morfológicas e produtivas do milho em diferentes épocas de semeadura. Cientí. 45:105-114.

Castro GSA, Costa CHM, Neto JF (2012) Ecofisiologia da aveia branca. Scie Agra Paran. 11:1-15.

Costa JSP, Mantai RD, Silva JAG, Scremin OB, Arenhardt EG, Lima ARC (2018) Single and split nitrogen dose in wheat yield indicators. Rev Bras de Eng Agrí e Amb. 22:16-21.

Ercoli L, Masoni A, Pampana S, Mariotti M, Arduini I (2013) As durum wheat productivity is affected by nitrogen fertilization management in Central Italy. Europ Jour of Agron. 44:38-45.

Flores RA, Urquiaga SS, Alves BJR, Collier LS, Morais RF, Prado RM (2012) Adubação nitrogenada e idade de corte na produção de matéria seca do capim-elefante no Cerrado. Rev Bras de Eng Agrí e Amb. 16:1282-1288.

Kaefer JE, Richart A, Nozaki MH, Daga J, Campagnolo R, Follmann P (2015) Canola response to nitrogen source and split application. Rev Bras de Eng Agrí e Amb. 19:1042-1048.

Mantai RD, Silva JAG, Sausen ATZR, Costa JSP, Fernandes SBV, Ubessi CA (2015) Eficiência na produção de biomassa e grãos de aveia pelo uso do nitrogênio. Rev Bras de Eng Agrí e Amb. 19:343-349.

Mantai RD, Silva JAG, Arenhardt EG, Scremin OB, Mamann ATW, Frantz RZ, Valdiero AC, Pretto R, Krysczun DK (2016) Simulation of oat grain (Avena sativa) using its panicle components and nitrogen fertilizer. Afri Jour of Agric Res. 11:3975-3983.

Marolli A, Silva JAG, Romitti MV, Mantai RD, Scremin OB, Frantz RZ, Sawicki S, Arenhardt EG, Gzergorczick ME, and Lima ARC (2017) Contributive effect of growth regulator Trinexapac-Ethyl to oats yield in Brazil. Afri Jour of Agric Res. 12:795-804. 
Moreira GBL, Pegoraro RF, Vieira NMB, Borges I, Kondo MK (2013) Desempenho agronômico do feijoeiro com doses de nitrogênio em semeadura e cobertura. Rev Bras de Eng Agrí e Amb-Agri. 17:818-823.

Santos RS, Costa LC, Sediyama GC, Leal BG, Oliveira RA, Justino FB (2011) Avaliação da relação seca/produtividade agrícola em cenário de mudanças climáticas. Rev Bras de Meteo. 26:313-321.

Scremin OB, Silva JAG, Mammann ATW, Marolli A, Mantai RD, Trautmann APB, Kraisig AR, Scremin AH, Kruger CAMB, Dornelles EF (2017) Nitrogen and hydrogel combination in oat grains productivity. Int J Devel Resea. 7:13896-13903.
Souza JLM, Gerstemberger E, Araujo MA (2013) Calibração de modelos agrometeorológicos para estimar a produtividade da cultura do trigo, considerando sistemas de manejo do solo, em Ponta Grossa-PR. Rev Bras de Meteo. 28:409-418.

Teixeira Filho MCM, Buzetti S, Andreotti M, Arf O, Benett CGS (2010) Doses, fontes e épocas de aplicação de nitrogênio em trigo irrigado em plantio direto. Pesq Agrop Bras. 45:797804.

Tonin RB, Ranzi C, Camera JN, Forcelini CA, Reis EM (2014) Amplitude térmica para germinação de conídios de Drechslera tritici-repentis. Sum Phyto. 40:174-177. 